\title{
Richtlijnen in de spreekkamer, van dogma naar dans
}

\author{
Citation for published version (APA):
}

van der Weijden, T. (2010). Richtlijnen in de spreekkamer, van dogma naar dans. Maastricht University. https://doi.org/10.26481/spe.20101126tw

Document status and date:

Published: 26/11/2010

DOI:

10.26481/spe.20101126tw

Document Version:

Publisher's PDF, also known as Version of record

\section{Please check the document version of this publication:}

- A submitted manuscript is the version of the article upon submission and before peer-review. There can be important differences between the submitted version and the official published version of record.

People interested in the research are advised to contact the author for the final version of the publication, or visit the DOI to the publisher's website.

- The final author version and the galley proof are versions of the publication after peer review.

- The final published version features the final layout of the paper including the volume, issue and page numbers.

Link to publication

\footnotetext{
General rights rights.

- You may freely distribute the URL identifying the publication in the public portal. please follow below link for the End User Agreement:

www.umlib.nl/taverne-license

Take down policy

If you believe that this document breaches copyright please contact us at:

repository@maastrichtuniversity.nl

providing details and we will investigate your claim.
}

Copyright and moral rights for the publications made accessible in the public portal are retained by the authors and/or other copyright owners and it is a condition of accessing publications that users recognise and abide by the legal requirements associated with these

- Users may download and print one copy of any publication from the public portal for the purpose of private study or research.

- You may not further distribute the material or use it for any profit-making activity or commercial gain

If the publication is distributed under the terms of Article $25 \mathrm{fa}$ of the Dutch Copyright Act, indicated by the "Taverne" license above, 


\section{Richtlijnen in de spreekkamer, van dogma naar dans.}

Mijnheer de rector magnificus, zeer gewaardeerde toehoorders,

Klinische praktijk richtlijnen zijn, zoals het woord zegt, aanbevelingen die richting geven en geen strikt opgelegde handelingen. Richtlijnen zijn niet dogmatisch bedoeld. Met deze rede wil ik duidelijk maken dat het toepassen van richtlijnen in de dagelijkse praktijk een dynamisch, patiëntgericht proces is waarbij beredeneerd afwijken van de richtlijnen juist de bedoeling is.

De rede bestaat uit twee delen:

In deel 1 geef ik mijn visie over patiëntgerichtheid in het toepassen van richtlijnen in de spreekkamer. In deel 2 presenteer ik in vogelvlucht wat we in onze groep doen aan onderzoek, en wat mijn plannen zijn voor de toekomst in onderwijs en onderzoek.

Ik probeer jargon zoveel mogelijk te vermijden. Zoals artsen hun eigen taal hebben, zo hebben ook wetenschappers hun eigen taal. Die eigen taal heeft een functie, net als de straattaal bij jongeren; het definieert een groep, het versterkt de binding binnen een groep, maar het sluit tegelijkertijd de anderen buiten.

Ik spreek in deze rede alleen over artsen, dat wil niet zeggen dat mijn ideeën exclusief zijn voor artsen. De rede is ook van toepassing op andere zorgverleners, zoals verpleegkundigen en fysiotherapeuten, die ook richtlijnen gebruiken.

\section{Deel 1) Richtlijnen in de spreekkamer, van dogma naar dans.}

De achtergrond van deze rede zijn medische keuzes. Ik geef u een paar voorbeelden:

Mevrouw Vlas lijdt onder een depressie en kan langdurend cognitieve gedragstherapie ondergaan, die confronterend kan zijn, of langdurend antidepressiva slikken, met de kans op bijwerkingen, of voor beide kiezen. Wat past het beste bij haar?

Meneer Bos heeft prostaatkanker die kan worden behandeld met bestraling. Er is een dilemma: de hoge bestralingsdosis geeft een hogere kans op overleving, maar ook meer kans op hinderlijke plasklachten, darmproblemen en erectiestoornissen. De lagere dosis geeft een wat lagere kans op overleving maar veel minder kans op die nare bijwerkingen. Wat past het beste bij hem?

Dit soort beslissingen, waarbij er meer dan één behandeloptie is, of dilemma's van voor- en nadelen, noemen wij in ons jargon preferentiegevoelige beslissingen.

Iedere patiënt is uniek en vergt, op de patiënt gericht, maatwerk. Dat maatwerk vereist een dialoog tussen arts en patiënt. Maar nu financiële vergoedingen voor artsen direct gekoppeld worden aan de mate waarin artsen werken volgens bepaalde richtlijnen - in de zogenaamde diagnose-behandel combinaties - dreigt het gevaar dat we richtlijnen dogmatisch gaan gebruiken. Tegelijkertijd moet de dialoog ook niet een verplicht karakter krijgen en een dogma op zichzelf worden. 


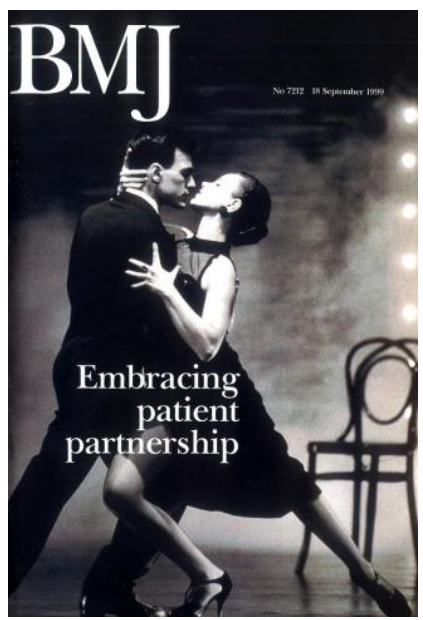

Daarom gebruik ik de metafoor van de dans die ik tegenkwam in het British Medical Journal. Dat ziet er mooi uit zo'n tango, maar dat is natuurlijk niet waar $u$ aan denkt als $u$ een arts moet bezoeken. En die erotische lading van dit beeld is al helemaal ongepast. Maar dans is zoveel meer dan de tango. Er zijn ook dansen die andere emoties uitdrukken, zoals verdriet, of toewijding, denk aan de dans van de sjamaan. De dans is een metafoor voor dynamiek in de spreekkamer, het gaat om het reageren op elkaar. De arts heeft de leiding maar past de dansstijl aan de patiënt aan. De patiënt beweegt mee met de arts, de arts beweegt mee met de patiënt. De arts moet meerdere ritmes beheersen en vlot kunnen schakelen tussen verschillende dansstijlen. Althans binnen de mogelijkheden van eigen lichaamstaal, de arts is immers ook maar een mens. De arts heeft kennis en macht, namelijk om te behandelen of niet te behandelen. De patiënt heeft kennis over wat het best bij hem of haar past, en ook macht, namelijk om het behandeladvies al dan niet op te volgen.

Ik wil de kernboodschap - dat richtlijnen toepassen een dynamisch proces is - verduidelijken met drie stellingen:

1) Toepassen van richtlijnen in de spreekkamer vergt een creatieve mix (een dans) van rationaliteit, intuïtie, en dialoog, resulterend in maatwerk voor de patiënt.

2) Het model van gezamenlijke besluitvorming is een haalbaar alternatief voor het paternalistisch model, maar geen nieuw dogma.

3) Richtlijnen moeten preferentiegevoelige beslissingen transparant maken.

Ik licht deze stellingen in de volgende 30 minuten toe.

Dit is de inhoud van het eerste deel:

- Evidence-Based Practice, ik leg deze term zo uit;

- Van Evidence Based Practice naar richtlijnen;

- Toepassen van richtlijnen in de spreekkamer;

- Gezamenlijke besluitvorming;

- Toepassen van gezamenlijke besluitvorming. 
Ik probeer het verschil tussen dogma en dans eerst wat concreter te maken met het verhaal van Tessie. Zij heeft regelmatig vocht achter het trommelvlies en is dan wat doof. Vroeger werd bij veel kinderen dan het trommelvlies doorgeprikt, de paracentese. Dat was de routine, het dogma. Toen is dit eens goed onderzocht en bleek dat het natuurlijke genezingsproces beter is dan het doorprikken, zeker nu we antibiotica achter de hand hebben. In de richtlijn van het Nederlands Huisarts Genootschap over oorontsteking wordt doorprikken dan ook afgeraden. Bij Tessie kunnen buisjes in de trommelvliezen geplaatst worden door de KNO-arts. De voordelen van de buisjes - ze hoort meteen beter - moeten worden afgewogen tegen de nadelen van de ingreep - het is een ingreep in het ziekenhuis, en er is een kleine kans op blijvende perforatie, en tegen het natuurlijke beloop, Tessie hoort wat langer slecht, maar wordt na enkele weken tot maanden vanzelf beter. Er is geen dogma maar een afweging die samen met de ouders wordt gemaakt.

\section{Evidence-Based Practice}

Dat onderzoek naar het nut van het doorprikken van het trommelvlies is een voorbeeld van kennisgebaseerde geneeskunde, de zogenaamde Evidence Based Medicine of Evidence Based Practice. De Evidence Based Practice bestaat nu zo'n 30 jaar. Eeuwenlang was de geneeskunde gebaseerd op de inzichten van de artsen met aanzien; de autoriteitgebaseerde geneeskunde. In de huidige complexe gezondheidszorg, met het toenemend aantal behandelopties en chronisch zieken, voldoet dit systeem niet meer. Archie Cochrane, een epidemioloog uit Cardiff, is de grondlegger van de Evidence Based Practice, met als uitvloeisel de Cochrane Library, een archief waar al het beschikbare medische bewijs bij elkaar staat.

Met wetenschappelijk bewijs bedoelen we feitenkennis gebaseerd op systematische waarnemingen, waarbij de kans op vertekening van de observaties door vooroordelen of vooronderstellingen minimaal wordt gehouden. Met die systematische waarnemingen kunnen we oorzaken van ziektes en effecten van behandelingen vaststellen. We komen dan op het domein van de klinisch epidemiologen. Het paradepaardje is het gerandomiseerde experiment. In zo'n experiment krijgen sommige patiënten een nieuwe behandeling en worden vergeleken met andere patiënten die de gangbare behandeling krijgen. Bijvoorbeeld, bij patiënten met een maagzweer krijgt een deel van de patiënten een antibioticum, en een ander deel de gangbare therapie, een maagzuurremmend middel. Het lot bepaalt in welke groep iedere patiënt komt, en de patiënt en de behandelaar weten niet welk middel de patiënt feitelijk krijgt. Zo kunnen we met vrij grote zekerheid vaststellen of het antibioticum beter werkt dan het maagzuurremmende middel.

Zo is vast komen te staan dat de maagzweer een infectieuze oorzaak heeft, een van de laatste doorbraken van de Evidence-Based Practice. En zo hebben we geleerd dat oren doorprikken en amandelen knippen meestal onnodig is. Dat twee weken platliggen voor een rughernia niet helpt, dat baby's die op de buik worden gelegd meer kans hebben op wiegendood, etcetera. Er zijn ook grote winsten geboekt op het gebied van vaccins en verbeterde behandeling van kanker. De investeringen in Evidence Based Medicine onderzoek hebben een goed rendement, zo bleek het rendement van cardiovasculair onderzoek, uitgedrukt in gezondheids- en economische winst, 9\% per jaar, en van geestelijk gezondheidszorgonderzoek $7 \%$ per jaar 
(Medical Research 2008). Dankzij de Evidence Based Practice is de kans op niet-werkzame behandelingen en op medische blunders veel kleiner geworden.

Dat is mooi zult u zeggen. En dat is het ook, ik ben een warme voorstander van de Evidence Based Practice. Maar er zijn kanttekeningen:

Het eerste probleem is het dogmatisch interpreteren van evidence. We moeten er voor waken om de kracht van het bewijs uit de experimenten zwaarder te laten wegen dan de relevantie van het bewijs (Montori 2008, Hochman 2010). Ik geef u wat redenen die evidence minder relevant kunnen maken. De metingen in de experimenten worden vaak beperkt tot relatief makkelijk te meten uitkomsten, die ook nog worden versimpeld naar afwijkend of niet-afwijkend, ziek of niet-ziek. Maar in werkelijkheid geldt voor bijna alle ziekten en klachten dat er veel grijstinten zijn tussen zwart en wit, tussen ziek en gezond. In het algemeen geldt dat de kennis die wordt vergaard in gestandaardiseerde experimenten waarbij interne validiteit voorop staat (efficacy), vaak niet goed aansluit bij de problemen in de praktijk (Thorpe 2009). Een ander probleem is dat complexe behandelingen niet zo makkelijk te evalueren zijn in gerandomiseerde experimenten vergeleken met een medicament. Denkt u aan fysiotherapie, psychotherapie, of interventies voor problemen als chronische lage rugpijn (Vos 2004). En soms worden nietrelevante stokpaardjes van onderzoekers, die nu eenmaal moeten publiceren, onderzocht. Of stokpaardjes van commerciële partijen zoals farmaceutische industrieën, die leiden tot medicalisering (Conrad 2010). Zo zijn angst-, melancholie-, slaap-, en erectieproblemen voorbeelden van gemedicaliseerde stoornissen. Door de industrie gefinancierd onderzoek komt vaak voor; in 2007 werd het biomedisch onderzoek in de USA voor 58\% door de industrie gefinancierd (Dorsey 2010).

Ten tweede is er het probleem van informatieoverload. De op bewijsgebaseerde kennis is niet bij te houden voor artsen (Glasziou 2005). Er worden iedere dag 1500 artikelen gepubliceerd. Om bij te blijven zouden artsen in 1995 al dagelijks meer dan 20 artikelen moeten lezen (Davidoff 1995). Hadden vroeger de artsen met de meeste ervaring de meeste en beste kennis, nu schieten artsen met meer ervaring juist relatief te kort in kennis over de nieuwste interventies ten opzichte van de jongere collega's. De opgebouwde routines wegen dus niet altijd meer op tegen het bijhouden van de nieuwe inzichten (Choudry 2005). En omdat de behandelmogelijkheden toenemen worden ook patiënten, zeker chronisch zieke patiënten, steeds meer beladen met adviezen en behandelingen. Om met de dichter TS Eliot te spreken; "Where is the wisdom we have lost in knowledge, where is the knowledge we have lost in information?".

\section{$\underline{\text { Van Evidence Based Practice naar richtlijnen }}$}

Deze problemen van dogmatisch gebruik van evidence en informatieoverload worden ondervangen door het ontwikkelen van klinische praktijkrichtlijnen door commissies van onafhankelijke experts. Of althans, het moet minimaal duidelijk zijn welke belangen de experts dienen. Goede richtlijnen vertrekken namelijk vanuit de behoeften van de gebruikers van de richtlijn, in tegenstelling tot de evidence, die soms geïnitieerd wordt vanuit andere belangen dan die van de zorgverleners in de spreekkamer. De allereerste richtlijn, over bloedtransfusie, werd in 
1982 door het CBO ontwikkeld. Het was toen vooral een consensus document. Het Nederlands Huisartsen Genootschap (NHG) leverde in 1989 haar eerste richtlijn voor huisartsen af, de diabetes richtlijn. Dat was niet alleen een manier om te professionaliseren (huisartsen werkten destijds met name solistisch en wilden medische ervaringen delen en daarvan leren) maar ook om te emanciperen. De huisartsen financieren hun eigen richtlijnen, grotendeels uit de contributiegelden van het de NHG-leden. De collectieve kennis is daardoor enorm verstevigd.

We lopen in Nederland voorop in de kwaliteit en methodiek van richtlijnontwikkeling. De richtlijncommissie stelt een beperkt aantal uitgangsvragen vast, zet alle relevante evidence op een rij, interpreteert die, en komt dan tot de aanbevelingen, rekening houdend met het gezondheidszorgbudget, en beschrijft de indicatoren en prestatienormen voor de kernaanbevelingen. In die interpretatieslag kunnen allerlei overwegingen meespelen, afhankelijk van het perspectief van de richtlijnontwikkelaar (Verkerk 2006). Ik geef u een voorbeeld: Uit experimenten was krachtig bewijs geleverd dat cholesterolverlagende medicatie, de zogenaamde statines, de kans op sterfte door een hart- of vaatziekte in 5 jaar van gemiddeld $1,7 \%$ naar 1,2\% verlaagt (voorbeeld ontleent aan Woscops trial Schotland). De hartchirurg in de commissie, die dagelijks patiënten met dichtgeslibde kransslagaderen ziet, denkt dan, dat is mooi, een verlaging van het risico met een-derde, en wil het voorschrijven van statines aan grote groepen patiënten aanbevelen. Maar de huisarts, die dagelijks patiënten ziet die jarenlang statines slikken en toch een hartinfarct ontwikkelen, en ook de verhalen hoort over bijwerkingen van de medicatie, denkt; het is een absolute verlaging van het risico met een $0,5 \%$, dus laten we dit alleen aan de echte hoog-risico patiënten voorschrijven. Beide experts hebben gelijk, ieder vanuit het eigen perspectief. Dit voorbeeld laat zien dat er geen 1-op-1 relatie is tussen evidence en aanbevelingen, en hoe belangrijk het is dat zowel huisartsen als ziekenhuis-specialisten betrokken zijn bij de ontwikkeling van richtlijnen. De interpretatie van de evidence wordt ondersteund door de GRADE criteria; deze criteria helpen om de evidence over het effect van een interventie te wegen in het licht van de beschikbare kennis over de bijwerkingen van de interventie, de waarden en voorkeuren van de patiënten-doelgroepen, en de impact op de gezondheidszorgbudgetten (Gyatt 2008). De kracht van multidisciplinaire richtlijnen is dat ze leiden tot werkafspraken tussen beroepsgroepen. Het ZonMW programma Kennis en Kwaliteit in de Curatieve Zorg (KKZC) heeft zich hier sterk voor gemaakt.

Ik ga nu niet verder in op de methodiek van richtlijnontwikkeling. De ontwikkelaars van klinische richtlijnen hebben zich wereldwijd georganiseerd en delen hun kennis in het GuidelinesInternational-Network, kortweg GIN genaamd (www.g-i-n.net). Nederland heeft een koppositie, dat blijkt al uit het feit dat Jako Burgers voorzitter is geweest, en sinds kort is dat Philip van der Wees. En in 2012 komt het GIN-congres naar Nederland.

In de richtlijncommissies zitten dus de experts bij elkaar. Patiënten zijn ook experts, maar dan in het ziek zijn, ze zijn ervaringsdeskundig. Ze horen ook een stem te hebben in richtlijnontwikkeling en kunnen het dogmatische gebruik van evidence verder indammen. Binnen een van de werkgroepen van GIN denken we na over hoe patiënten in richtlijnontwikkeling betrokken kunnen worden. De richtlijn wordt niet alleen gericht op de problemen die artsen belangrijk vinden, maar ook op de problemen die patiënten belangrijk vinden. Nu zult u zich afvragen; zit 
daar dan verschil tussen? Ja, dat kan voorkomen. Ik geef u een voorbeeld uit de reumatologie, waar reumatologen en patiënten samen discussieerden over belangrijke uitgangsvragen. Dit leidde ertoe dat niet alleen de behandeling van de ontstoken gewrichten aandacht kreeg, maar ook vermoeidheid waar veel reumapatiënten mee kampen, een onderwerp dat aanvankelijk niet op de agenda van de artsen stond (Kirwan 2007). Ontstekingsprocessen zijn namelijk veel makkelijker te meten dan vermoeidheid, en daarom is er minder evidence over de behandeling van vermoeidheid.

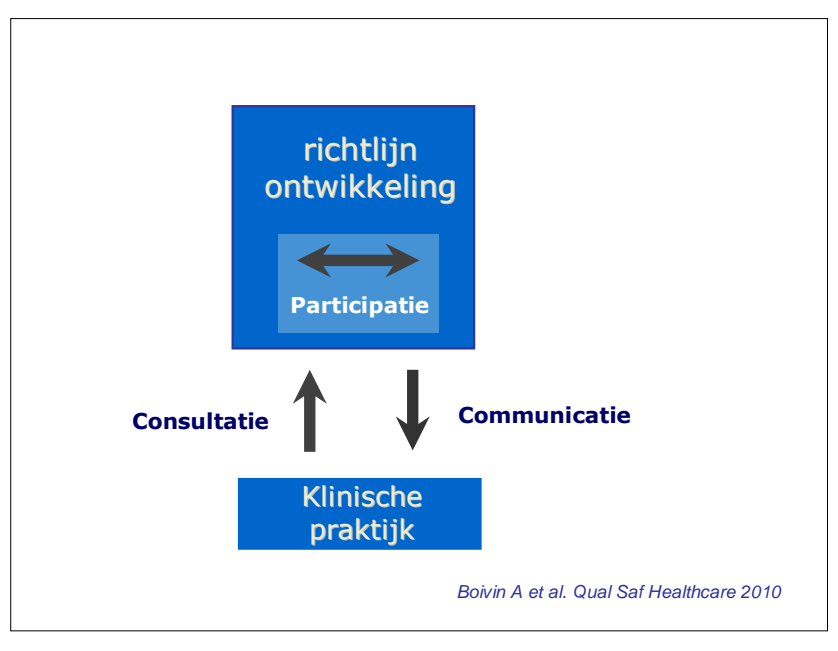

Er zijn drie manieren om het patiëntenperspectief in richtlijnen in te brengen (Boivin 2010). Consultatie: Patiënten kunnen door een richtlijncommissie bevraagd worden naar hun ervaringen en wensen in de klinische praktijk, of naar wat ze vinden van de concept-richtlijn. Communicatie: Als de richtlijn eenmaal klaar is kan een patiëntenversie van de richtlijn gemaakt worden, zodat patiënten weten wat ze in de spreekkamer kunnen verwachten. Of participatie: het daadwerkelijk meedoen aan het ontwikkelen van de richtlijn.

Dat daadwerkelijk meedoen aan richtlijnontwikkeling staat nog in de kinderschoenen, en vaak loopt het nog niet goed (van de Bovenkamp 2009). Opvallend is dat patiëntenvertegenwoordigers moeten "bewijzen" dat ze verder kunnen kijken dan alleen hun eigen ervaring, hun eigen belang. Daar moeten ze bovenuit kunnen stijgen. Tegelijkertijd komt het voor dat professionals die zitting hebben in de richtlijn alleen hun eigen stokpaardjes berijden, en niet boven de partijen uitstijgen. We hebben geleerd dat patiëntvertegenwoordigers vanaf het begin moeten worden betrokken en in alle fasen van de richtlijnontwikkeling, meer of minder intensief, maar zeker bij het vaststellen van de uitgangsvragen voor de richtlijn. Er worden verschillende werkwijzen gehanteerd, afhankelijk van de kenmerken van de aandoening (bijv. zeldzame ziekten, onverklaarbare klachten, chronische aandoeningen, geestelijke gezondheidszorg, gehandicaptenzorg) en de kenmerken van de betrokken patiëntenorganisatie. Ik citeer een paar principes uit rapporten over patiëntenparticipatie in richtlijnontwikkeling (Légaré 2009, Broerse 2010, CBO 2010): 
- Systematische werving van minimaal twee patiëntvertegenwoordigers (vacatures plaatsen);

- Patiënten vanaf begin betrekken, en in alle fasen van richtlijnontwikkeling;

- Rol en taken van de patiëntenvertegenwoordigers duidelijk vastleggen;

- Patiënten betalen voor reiskosten, vacatiegelden;

- Patiënten trainen in methodologie van richtlijnontwikkeling;

- Goede voorzitter, die getraind is in patiëntenparticipatie;

- Alle relevante wetenschappelijke literatuur betrekken.

Wat dat laatste betreft ligt er een taak, bijvoorbeeld voor patiëntenverenigingen, om goede publicaties, ook kwalitatieve studies, die het patiëntenperspectief beschrijven, te inventariseren ten behoeve van de richtlijncommissies. Er wordt door sommigen een onderscheid gemaakt in kennis en waarden-gerelateerde aspecten van richtlijnontwikkeling, waarbij vooral bij de waarden-discussies een rol voor de patiënten wordt gezien (Légaré 2010). In werkelijkheid is dat onderscheid moeilijk te maken (Moreira 2005, Boivin 2008, Lehoux 2009).

\section{$\underline{\text { Toepassen van richtlijnen in de spreekkamer }}$}

Maar hoe worden dan die richtlijnen toegepast in de spreekkamer? Dat gaat vaak goed.

Huisartsen handelen gemiddeld voor 60 tot $70 \%$ volgens de richtlijnen voor het voorschrijven van geneesmiddelen aan de juiste patiënten (www.gezondheidszorgbalans.nl). Dat lijkt misschien wat laag maar er zijn vaak belangrijke redenen om van de richtlijnen af te wijken, zoals polifarmacie of multi-morbiditeit. Maar u ziet ook dat er flinke variatie is. Variatie tussen artsen moet er zijn, richtlijnen zijn immers geen dogma.

Maar er is ook ongewenste variatie tussen artsen, zeker in volumes. Bijvoorbeeld huisarts A schrijft 4x zoveel statines voor per 1000 patiënten vergeleken met huisarts B. Dat verschil is zo groot dat het niet meer verklaard kan worden door medische verschillen tussen de patiëntengroepen van huisarts $A$ en huisarts $B$, maar veeleer verklaard wordt door verschillen in voorschrijfroutines tussen huisarts A en B. Dan spreken we van ongewenste interdokter variatie. Dat zien we ook in diagnostiek; De huisartsen in regio Sittard vragen gemiddeld twee keer zoveel laboratoriumtests aan als de huisartsen in Nijmegen (Verstappen 2004). En zo is er in medischspecialistische zorg een variatie tussen regio's in het aantal baarmoederverwijderingen met een factor 8, en het aantal galblaasoperaties met een factor 15 (Berg 2008). Vaak is er dan sprake van overbodig en onnodig toepassen van diagnostiek en behandeling (Wennberg 2002). Het blijkt dat veel artsen meer worden gevormd door lokale gebruiken dan door de richtlijnen. Waar patiënten leven en welke dokter ze consulteren bepaalt meer hun behandeling dan de richtlijn en wat de patiënt belangrijk vindt (Mulley 2009).

Een tweede probleem met het toepassen van de richtlijnen is onzekerheid. De EvidenceBased Practice heeft ons veel goeds gebracht, maar ook een ongemakkelijke waarheid. Voor veel tests en behandelingen, waarvan we vroeger overtuigd waren dat ze werkzaam waren, is gebleken dat ze niet of maar voor een enkele patiënt werken. Maar patiënten geloven dat hoe meer zorg, en hoe duurder, hoe beter (Carman 2009). Dat is dus helaas niet waar, en ook gevaarlijk, want 
behandelingen hebben ook de risico's van onbedoelde bijwerkingen. We moeten patiënten ontnuchteren in overspannen verwachtingen van de geneeskunde, en tegelijkertijd troost bieden.

Een derde probleem is het opvolgen van adviezen door patiënten. Gemiddeld houdt $75 \%$ van de patiënten zich aan de medische voorschriften en adviezen (DiMatteo 2004). Voor langdurige medicamenteuze behandeling is dat slechts $50 \%$, en voor leefstijladviezen nog veel lager (Sabaté 2003). De arts-patiënt relatie doet er blijkbaar toe, want er is verschil tussen de zorgverleners en de mate van therapietrouw van hun patiënten (van Dulmen 2010).

Maar hoe gaat dat toepassen van die richtlijnen dan in die spreekkamer? De klinische besluitvorming is complex en wordt bepaald door minstens 3 factoren.

\section{Klinische besluitvorming}

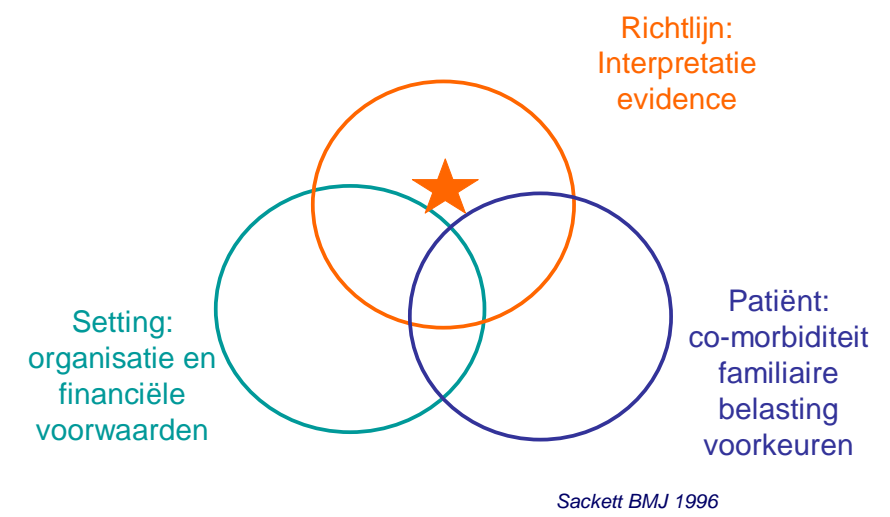

De oranje cirkel stelt de ruimte voor waarbinnen de arts zich kan bewegen volgens de richtlijn.

Hoe meer in het midden, hoe meer zij handelt volgens de aanbeveling, de ster. Nu kan de arts nog zo goed volgens de aanbeveling willen handelen, toch kunnen er allerlei redenen zijn waarom zij van die aanbeveling afwijkt. De huisarts heeft immers veel bagage bij zich; niet alleen de richtlijn, maar ook routines, ervaring, en intuïtie zoals het niet-pluis gevoel (Stolper 2009). En dan is er de omgeving waarin de arts werkt die bepaalde kenmerken heeft, bijvoorbeeld een bepaald type organisatie of diagnose-behandel-combinatie vergoeding, waardoor het werken volgens de richtlijn wordt gefaciliteerd of juist gehinderd. En last but not least de patiënt. Een uniek individu met een speciaal profiel wat betreft ziekte en risicofactoren, co-morbiditeit en familiaire aanleg voor ziekte, en ook allerlei bagage zoals sociale omstandigheden, culturele waarden, angsten, wensen en voorkeuren waardoor de arts uiteindelijk bijna of helemaal afwijkt van de richtlijn (Sackett 1996).

Dat brengt mij tot de eerste stelling:

Toepassen van richtlijnen in de spreekkamer vergt een creatieve mix van rationaliteit, intuïtie, en dialoog, resulterend in maatwerk voor de individuele patiënt. 


\section{Gezamenlijke besluitvorming}

Voor dat maatwerk kan gezamenlijke besluitvorming een goed alternatief zijn voor het paternalistisch model. Het model van gezamenlijke besluitvorming in de spreekkamer kan helpen om de problemen van ongewenste interdokter variatie, onzekerheid en therapieontrouw het hoofd te bieden.

Mijnheer Janssen, een gezonde man van 62 jaar, komt met een schimmelinfectie van de huid bij de huisarts, maar de huisarts maakt zich zorgen over zijn risico op hart- en vaatziekten. De praktijkondersteuner brengt het risico in kaart door bloeddruk en cholesterolwaarden te meten.

Stalman, P.d.W.A.B., et al., NHG-standaard: M84: Cardiovasculair risicomanagement. Huisarts en wetenschap, 2006

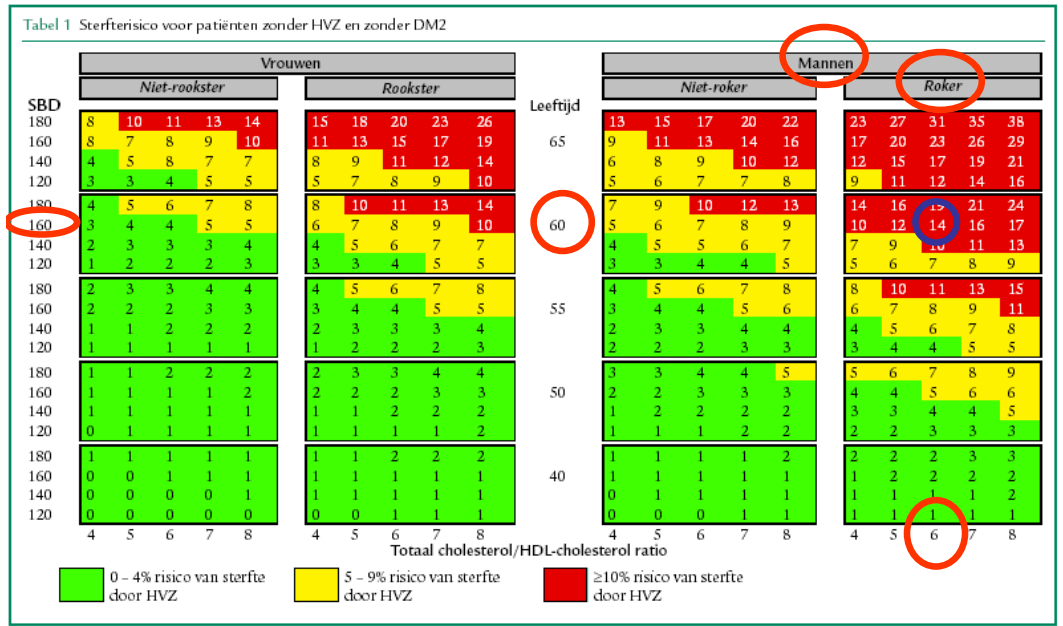

Hier ziet u de richtlijn voor cardiovasculair risicomanagement van het Nederlands Huisartsen Genootschap, de risicotabel (NHG 2006). Deze richtlijn is een goed voorbeeld van de trend dat specifieke aanbevelingen steeds meer van groeps- naar geïndividualiseerd niveau zullen verschuiven. Mijnheer Janssen is een man, van begin 60, hij rookt, hij heeft een bovendruk van $160 \mathrm{mmHg}$, en een cholesterolratio van 6. Dat betekent dat hij een absoluut risico heeft van $14 \%$ om in de komende 10 jaar dood te gaan aan een hart- of vaatziekte. Ter vergelijking, in het ideale geval is zijn risico 3\%. Mijnheer Janssen zit in het rood, zijn risico op hart- en vaatziekten is verhoogd en hij komt in aanmerking voor bloeddruk- of cholesterolverlagende medicatie. Er zijn meerdere wegen naar Rome, meerdere manieren om mijnheer Janssen's risico wat te normaliseren. We kunnen voluit gaan en hem zowel bloeddruk- als cholesterolverlagers voorschrijven, hem adviseren af te vallen (hij is nogal zwaar), en te stoppen met roken. Maar dat is meer dan een normaal mens aan kan. Het moet stap voor stap, maar als we zien dat het effect van bloeddrukverlaging of stoppen met roken vergelijkbaar is, welke stap nemen we dan als 
eerste? Daarom is ook dit een preferentiegevoelige beslissing. We moeten, samen met mijnheer Janssen, op zoek naar een passend behandelplan waar hij zelf ook achter staat.

Het klassieke paternalistische artspatiëntmodel schiet tekort in geval van preferentiegevoelige beslissingen, als er meerdere wegen naar Rome of dilemma's zijn. In het paternalistisch model geeft de arts informatie over diagnose en behandelopties. De arts wikt en weegt de opties. En de arts neemt de beslissing. Het andere uiterste is het model van de geïnformeerde patiënt. De arts geeft informatie over diagnose en behandelopties. De patiënt wikt en weegt, en neemt een besluit. Hoewel het beeld bestaat dat patiënten steeds veeleisender worden, is gebleken dat slechts $1 \%$ van de Canadese patiënten dit laatste als een wenselijk model ziet (Deber 2007).

Er is een tussenmodel (Charles 1999). Dat ziet er als volgt uit.

\section{Gezamenlijke besluitvorming}

\begin{tabular}{|c|c|c|c|}
\hline & Paternalisme & $\begin{array}{c}\text { Gezamenlijke } \\
\text { besluitvorming }\end{array}$ & $\begin{array}{c}\text { Geïnfor- } \\
\text { meerde } \\
\text { patiënt }\end{array}$ \\
\hline $\begin{array}{c}\text { Informatie- } \\
\text { transfer }\end{array}$ & arts & arts en patiënt & patiënt \\
\hline $\begin{array}{c}\text { Wikken en } \\
\text { wegen }\end{array}$ & arts & arts en patiënt & patiënt \\
\hline $\begin{array}{c}\text { Besluit } \\
\text { vorming }\end{array}$ & & \\
\hline
\end{tabular}

Charles et al. Decision-making in the physician-patient encounter. Soc Sci Med 1999;49:651-61.

De arts legt uit dat er meerdere behandelopties zijn, dat er wat te kiezen is, de zogenaamde equipoise (Elwyn 2000). De behandelopties worden geschetst, met informatie over de kansen op effecten en bijwerkingen, die op een neutrale manier wordt gegeven. De onzekerheden van de Evidence worden uitgelegd aan de patiënt. De patiënt geeft informatie over zijn of haar angsten, bedenkingen en wensen.

Dan volgt het wikken en wegen, oftewel deliberatie, over de opties. De arts kan een behandeloptie aanbevelen. De patiënt brengt zijn of haar voorkeur naar voren. De arts moet luisteren en proberen te begrijpen waarom de patiënt eventueel een andere optie wil kiezen. Veel patiënten hebben hier hulp bij nodig, daar kom ik later op terug.

Tot slot wordt een beslissing genomen. Soms schikt de patiënt zich naar de arts, soms de arts naar de patiënt, maar meestal is er consensus.

Het is overigens prima, als de patiënt echt niet betrokken wil worden, dat de arts en patiënt overeenkomen om het paternalistisch model toe te passen. Velen zouden graag de arts als de perfecte zaakwaarnemer zien in zo'n beslisproces. De patiënt delegeert dan de beslisautoriteit naar de dokter. Maar dan moet de arts ook perfect in staat zijn om te achterhalen wat de voorkeuren en wensen zijn van de patiënt. Dat is per definitie niet goed mogelijk, de patiënt moet 
vaak zelf nog achterhalen wat hij/zij precies wil, in samenspraak met zijn/haar achterban, dus de arts als de perfecte zaakwaarnemer is niet meer dan een theoretisch concept (Gafni 1998).

Dit model van gezamenlijke besluitvorming in de spreekkamer ziet er misschien wel helder uit maar de werkelijkheid is natuurlijk veel complexer. Vele individuen naast de arts en patiënt kunnen betrokken zijn, collega's van de arts, en partner, familie en vrienden van de patiënt. Lang niet alle beslissingen zijn urgent. Gezamenlijke besluitvorming is vaak een geleidelijk proces dat zich over verschillende consulten verspreid (Rapley 2008, Légaré 2008). Ideale modellen van hoe de mens denkt gaan ervan uit dat we rationele afwegingen maken tussen de kans op de consequentie van het besluit, en hoe we die consequentie waarderen (Baron 1996). Maar we zijn ons meestal niet bewust hoe we beslissen, we gebruiken vaak vaste denkpatronen, laten ons leiden door emoties, en zijn misschien wel veel meer heteronoom - we worden beïnvloed in onze keuzes door allerlei signalen en factoren in onze omgeving -, dan autonoom. (Acker 2008, WRR 2009). Het gaat niet zozeer om de beslissing zelf, maar om het verbeteren van het proces van de besluitvorming (Bekker 2003).

In de UK heerst nu het adagium "no decision about me, without me". Maar "patiënten willen niet kiezen" is een veelgehoorde kreet. Het boek van Gonny ten Haaft, "Dokter is ziek" laat zien dat zelfs zeer deskundige patiënten niet altijd op elk moment mondig zijn. Gezamenlijke besluitvorming moet geen dogma worden. In onzekerheid verkeren over wat te doen kan kwellend zijn (McNutt 2004). Toch blijkt uit onderzoek dat een grote meerderheid van de patiënten actief betrokken wil worden in belangrijke keuzes (Coulter 2005, Deber 2007, Coulter 2010, NPCF 2010), en dat artsen deze wens onderschatten (Stalmeier 2007). Bovendien is de wens om betrokken te zijn geen stabiel kenmerk van de patiënt (Llewleyn-Thomas 2006). Die wens neemt toe zodra de patiënt zich realiseert dat er wat te kiezen valt, en dat er voor- en nadelen aan de behandeling zitten. Ook blijkt dat patiënten die al eens actieve betrokkenheid hebben meegemaakt het vaker willen (Thornton 2003).

Een keuzehulp is een belangrijk ondersteunend middel voor gezamenlijke besluitvorming. Een keuzehulp kan een boekje, een cd-rom of een website zijn, en door de patiënt thuis bekeken worden, of tijdens het consult met de arts. Een voorbeeld van een keuzehulp over screening op prostaatkanker met de PSA-test is beschikbaar op de website van VWS "kiesbeter.nl”. Een goede keuzehulp beschrijft 1) het specifieke besluit dat moet worden genomen en geeft een overzicht van de opties, inclusief de optie om af te wachten. 2) De voor- en nadelen per optie worden beschreven aan de hand van uitkomsten die relevant zijn voor de gezondheid en voor kwaliteit van leven. 3) De kansen op de uitkomsten worden op een neutrale manier beschreven, volgens de inzichten van de risicocommunicatie, dus niet alleen woorden, maar ook cijfers en grafische weergave (Paling 2003). Het kan een moeilijke boodschap zijn. Zo kan de PSA-test een afwijkende uitslag geven bij mannen die nooit kanker zullen krijgen, en dan tot onnodige prostaatbiopten leiden, en andersom, een goede uitslag bij mannen die toch kanker krijgen. Een $100 \%$ betrouwbare test komt helaas amper voor in de geneeskunde. 4) Patiënten worden geholpen om hun voorkeuren te verhelderen, te construeren, en te benoemen. 5) Tot slot beschrijft de keuzehulp een stappenplan in de besluitvorming. 
De criteria voor een goede keuzehulp zijn beschreven in de International Patient Decision Aids Standards (IPDAS) criteria (Elwyn 2006, Elwyn 2009).

Heeft gezamenlijke besluitvorming wel het gewenste effect? Er is een systematisch overzicht in de Cochrane Library van 55 gerandomiseerde experimenten waarin patiënten die gezamenlijke besluitvorming kregen, inclusief keuzehulp, werden vergeleken met patiënten die de gebruikelijke voorlichting kregen (O’Connor 2007). De patiënten in de experimentele groep hadden meer kennis, waren meer betrokken bij het deliberatieproces, en de gemaakte keuzes pasten meer bij de voorkeuren van de patiënten. Er is een trend naar een gunstig effect op therapietrouw maar dat is niet significant. Ze kozen $24 \%$ minder vaak voor invasieve (vooral chirurgische) procedures. Dit heeft niet geleid tot negatieve effecten op de gezondheid. Ook niet op angst van patiënten, of op de consultduur. Er zijn overigens ook geen positieve effecten op gezondheid gevonden. De vraag is of je dat kunt verwachten; het gaat immers om dilemma's waarbij er meestal gelijkwaardigheid is tussen de opties.

Overigens lijken keuzehulpen in de preventieve geneeskunde een paradoxaal effect te hebben, door Geoffrey Rose 30 jaar geleden al de preventieparadox genoemd (Rose 1991). Screening kan op populatieniveau, gegeven dat iedereen meedoet, wel kosteneffectief zijn, maar voor het individu is de absolute winst maar heel klein. Een keuzehulp over screening op darmkanker met de faeces occult bloed test leidde bij de deelnemers die de keuzehulp hadden gekregen tot 59\% deelname aan de test vergeleken met $75 \%$ in de controlegroep (Smith 2010). De consequentie van gezamenlijke besluitvorming in de publieke gezondheidszorg kan dus zijn dat minder mensen meedoen aan screening. Dat geeft stof tot nadenken. Momenteel woedt een debat over het bewust beïnvloeden van mensen in hun keuzes, vooral ten aanzien van gezond gedrag, screening en vaccinaties, uitgedrukt als "nudging", engels voor een vriendelijk duwtje in de goede richting.

Samenvattend, hoewel patiënten op het eerste gezicht denken "hoe meer zorg, hoe beter" (Carman 2009), blijkt dat, wanneer patiënten eenmaal geïnformeerd zijn over de behandelopties en de voor- en nadelen, patiënten vaker dan artsen voor conservatieve behandeling of voor afwachten kiezen, vaker voor kwaliteit van leven dan voor levensverlenging. Benadrukt moet worden dit in het algemeen geldt. We weten niet hoe het voor een individu in de spreekkamer is. Een individu met masochistische trekken kan immers heel anders over pijn en pijnbestrijding denken dan de massa.

Dit brengt mij tot de tweede stelling:

Het model van gezamenlijke besluitvorming, inclusief de keuzehulp, moet een rë̈el en haalbaar alternatief zijn voor het paternalistisch model, zonder een nieuw dogma te worden.

\section{Toepassen van gezamenlijke besluitvorming}

Hoewel er op kiesbeter.nl al 16 keuzehulpen beschikbaar zijn, en in een internationale database zelfs meer dan 250 (http://decisionaid.ohri.ca), zijn keuzehulpen onder artsen en patiënten nog nagenoeg onbekend. Onder artsen is er weerstand want ze houden er niet van om patiënten op te 
zadelen met onzekerheid, en het vergt een andere manier van werken, en we zijn nu eenmaal niet zo makkelijk af te brengen van onze routines (Elwyn 2008).

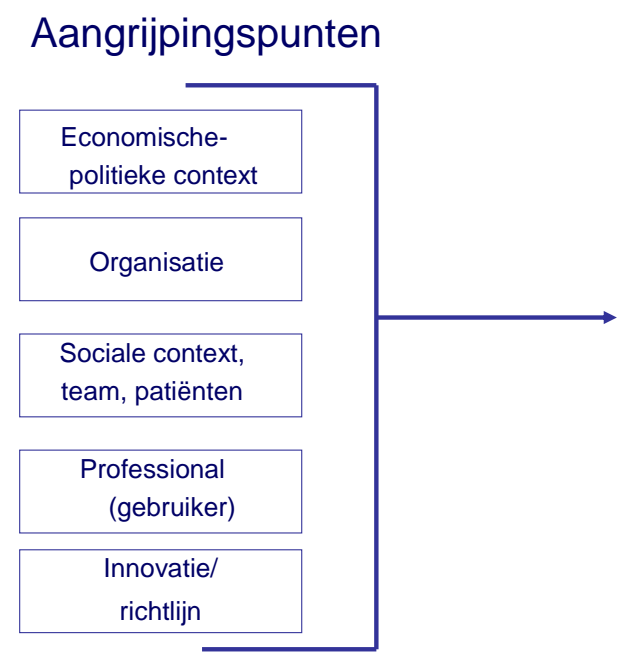

\section{Implementatie}

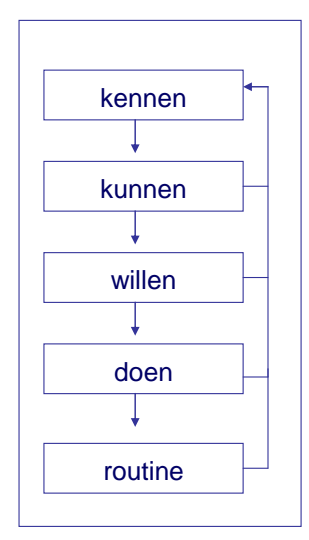

Fleuren et al. Int J Qual Health Care 2004;16:107-23.

Hier ziet u de basale voorwaarden om gezamenlijke besluitvorming in te voeren. Artsen moeten het kennen, kunnen, willen en dan echt gaan doen (Grol 2004). In zo'n veranderingsproces kunnen we meerdere aangrijpingspunten onderscheiden (Fleuren 2004). Uiteraard het niveau van de zorgverleners zelf. Ik denk dat generieke scholing minder zinvol is en dat scholing over gezamenlijke besluitvorming gekoppeld moet zijn aan een specifieke richtlijn met een relevante preferentiegevoelige aanbeveling.

Alleen scholing van artsen zal niet genoeg zijn. Het is ook van belang dat de arts gesteund wordt door de leidinggevende, en dat alle teamleden dezelfde kennis en motivatie hebben (Towle 2006). De patiënt moet ook goed ondersteund worden, dan is namelijk de mate van geletterdheid geen struikelblok voor participatie in de spreekkamer. De patiënt kan ook een activerende rol spelen. In een review van 33 experimenten waarin patiënten vóór een consult werden geïnstrueerd om de vragen die ze wilden stellen ook echt te stellen, bleek dat er inderdaad wat meer vragen werden gesteld en dat de tevredenheid van patiënten iets toenam. Maar het is geen wondermiddel (Kinnersley 2008). Desondanks proberen ze in de USA patiënten aan te zetten om de artsen meer te gaan bevragen door advertenties op TV. Dit soort strategieën kunnen zinnig zijn als hierdoor het handelen van de artsen in het algemeen wordt verbeterd. Als echter alleen het handelen van de artsen verbetert bij patiënten die de gewenste assertiviteit vertonen, leidt het tot een ongewenste tweedeling in de zorg, ten nadele van de minder assertieve patiënten.

De organisatie moet het faciliteren door bijvoorbeeld gezamenlijke besluitvorming te integreren in lokale klinische protocollen. Of door tijd te maken voor het coachen van patiënten 
door verpleegkundigen. Goede keuzehulpen moeten voortdurend beschikbaar zijn op de route van de patiënt door de zorg.

Op het niveau van regulering hebben we in Nederland de politieke wind mee (RVZ 2010). Nederland loopt voorop met de Wet op de Geneeskundige Behandelovereenkomst (de WGBO) waarin gezamenlijke besluitvorming staat vastgelegd.

Ik geef u nu een voorbeeld uit eigen keuken om te laten zien hoe we gezamenlijke besluitvorming hebben geïmplementeerd (Koelewijn 2009, Koelewijn 2010). Om voor mijnheer Janssen (uit het voorbeeld over cardiovasculair risicomanagement) tot een passend geïndividualiseerd behandelplan te komen kregen praktijkondersteuners een 2-daagse training in de richtlijn, in risicocommunicatie, en in gezamenlijke besluitvorming. Ze kregen een kaart om het risico grafisch weer te geven, en een keuzehulp om mee te geven aan de patiënt. In de keuzehulp staat de risicotabel uit de richtlijn weergegeven. De beslissing werd altijd uitgesteld naar een tweede consult. Ondertussen is de keuzehulp voor iedereen beschikbaar op kiesbeter.nl. Mijnheer Janssen kan dit nu dus ook thuis invullen. Maar dit is dus nagenoeg onbekend.

Dat brengt mij op het laatste aangrijpingspunt voor succesvolle implementatie, en zijn we weer terug bij de richtlijn.

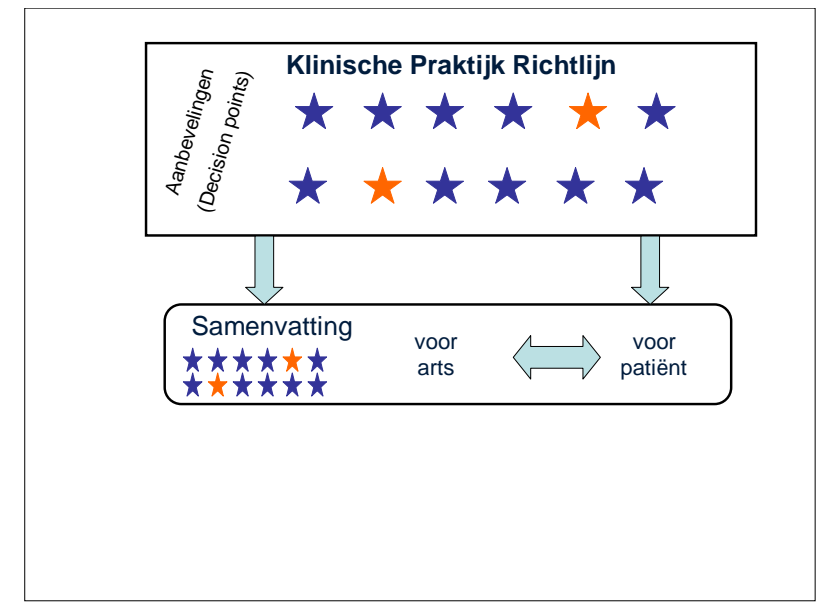

Dit stelt een klinische praktijkrichtlijn voor. Dat is meestal een groot document met tientallen aanbevelingen, hier weergegeven met de sterren. De blauwe sterren zijn sterke aanbevelingen, zoals het voorschrijven van een lage dosering aspirine bij patiënten die een hartinfarct hebben gehad. Het is een effectieve behandeling, met weinig bijwerkingen, er zijn geen aanwijzingen dat patiënten heel andere voorkeuren hebben dan artsen, en het is doelmatig. De oranje sterren zijn voorbeelden van preferentiegevoelige beslissingen. De richtlijn moet heel gebruiksvriendelijk worden aangeleverd, door een goede samenvatting. Idealiter levert de richtlijncommissie ook een patiëntenversie van de richtlijn af, die naadloos past bij de versie voor de arts, zodat de patiënten kunnen weten wat de richtlijnaanbevelingen zijn. 


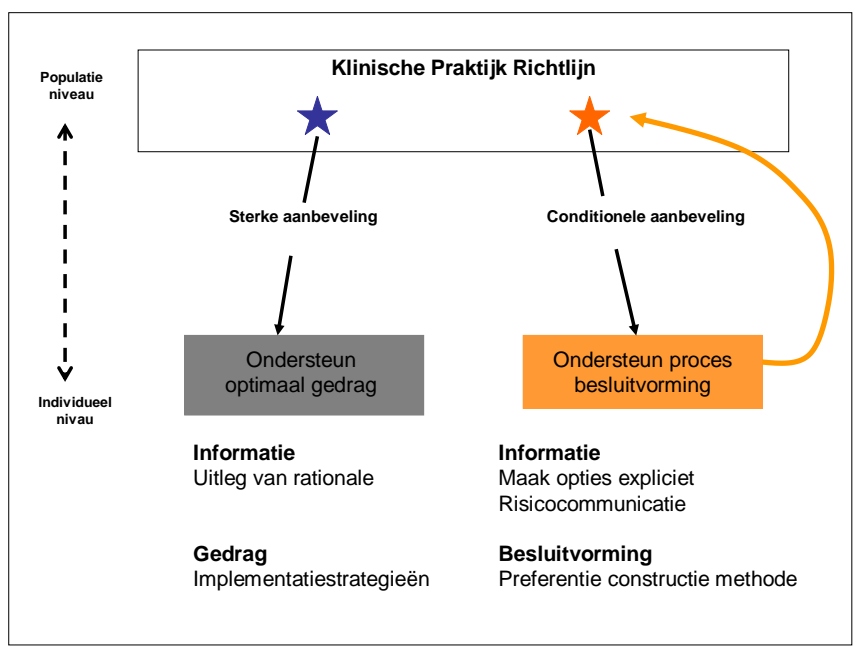

En als we kijken naar specifieke tools voor implementatie die we in het richtlijndocument aan aanbevelingen kunnen koppelen, dan moeten we aan de sterke aanbevelingen andere tools koppelen dan aan de preferentiegevoelige aanbevelingen. Bij de eerste gaat het bijvoorbeeld om feedback strategieën voor de arts en therapietrouw-bevorderende strategieën voor de patiënt, meer in een overredende toon, de sfeer van "nudging". Bij de preferentiegevoelige aanbevelingen gaat het om tools die het proces van de besluitvorming verbeteren, liefst complete keuzehulpen, waarvan de kern - het neutrale overzicht van opties met voor- en nadelen- wordt geïntegreerd in de richtlijn (van der Weijden 2010).

En dat brengt mij tot de laatste stelling:

Bij richtlijnontwikkeling komen de dilemma's en onzekerheden bij het toepassen van medische kennis bloot. De richtlijn moet dit niet toedekken maar transparant maken, en een keuzehulp voor patiënten koppelen aan de preferentiegevoelige aanbevelingen.

Ik hoop u nu wat meer duidelijk gemaakt te hebben dat het toepassen van richtlijnen in de dagelijkse praktijk een dynamisch, patiëntgericht proces is waarbij beredeneerd afwijken van de richtlijnen juist de bedoeling is. Dan kom ik nu aan het tweede deel van mijn rede.

Deel 2) Het huidige kwaliteit van zorg onderzoek en plannen voor onderwijs en onderzoek.

Wij bouwen voort op de expertise die door mijn voorganger op de leerstoel, Richard Grol, en zijn Formatted: Font: $11 \mathrm{pt}$ groep is vastgelegd in de implementatiebijbels (Grol 2005, Grol 2006). 

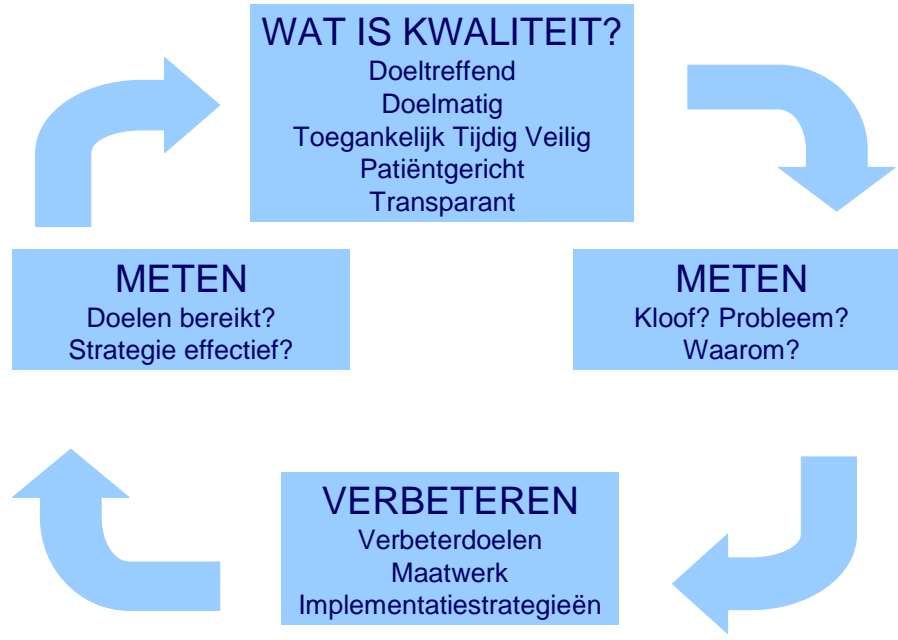

\section{METEN Kloof? Probleem? Waarom?}

De kwaliteitscyclus is de basis van ons onderzoek. We stellen een norm vast voor kwaliteit en ook de marges daarin, meestal in de vorm van klinische praktijkrichtlijnen. Op de eerste plaats moet de zorg die we leveren doeltreffend zijn, werkzaam, en doelmatig. En toegankelijk, tijdig en veilig. Patiëntgerichtheid is een aparte dimensie. Daar ging het eerste deel van deze rede over. Tot slot moeten we als professionals ook transparant zijn.

We gaan dan meten hoe de huidige zorg zich verhoudt tot de norm zoals vastgelegd in een richtlijn. We meten aan de hand van gevalideerde indicatoren op structuren, processen en patiëntenuitkomsten. Als we dan een kloof vinden tussen de werkelijke zorg en de richtlijn, analyseren we waarom die kloof bestaat door een knelpuntenanalyse. Hiervoor gebruiken we vaak kwalitatieve methoden.

Pas dan zijn we in staat om te onderbouwen hoe we kunnen verbeteren, en wat daarvoor een goede implementatiestrategie zou kunnen zijn. Er zijn geen magic bullets voor succesvolle implementatie van richtlijnen, we moeten duidelijke en haalbare doelen stellen en steeds maatwerk leveren. Implementatiestrategieën gebaseerd op een knelpuntenanalyse zijn namelijk effectiever dan de niet probleemgeoriënteerde implementatiestrategieën (Baker 2010).

Om de kwaliteitscyclus te sluiten doen we gerandomiseerde of quasi-experimentele studies om te evalueren of de implementatiedoelen bereikt zijn en of de implementatiestrategie daaraan effectief had bijgedragen. We kijken niet alleen naar effecten maar ook naar processen en kosten. Kwaliteit bereiken en behouden kost immers geld en dat moeten we goed in kaart brengen.

Onze projecten gaan uiteraard veel over richtlijnen. We hebben projecten gericht op het verbeteren van het handelen van huisartsen. Jasper Trietsch probeert de infrastructuur voor intercollegiale toetsing over volumes van laboratoriumtesten en geneesmiddelen (het zogenaamde DTO en FTO) te verbeteren, en Jos Boesten onderzoekt of gevalideerde prescriptie-indicatoren en Formatted: Font: $11 \mathrm{pt}$ Formatted: Comment Text, Indent: First line: $0 \mathrm{~cm}$

Formatted: Font: $11 \mathrm{pt}$ een door hem ontwikkelde webbased feedback module daaraan kunnen bijdragen. Paul Houben 
heeft aangetoond dat we niet te ver moeten doorschieten in terugdringen van overbodige testaanvragen, want huisartsen weten goed om te gaan met resultaten van zogenaamde overbodige tests. Arianne Theuws ontwikkelt een model voor de financiële borging van implementatie van veelbelovende zorginnovaties voor ouderen. We doen ook implementatieprojecten buiten de huisartsgeneeskunde; zo hebben Mascha de Kok en Jose Maessen de peri-operatieve zorg voor borstkanker en dikkedarmkanker patiënten succesvol verbeterd.

Andere projecten gaan vooral in op het patiëntenperspectief. Marika Burda onderzoekt hoe we de zorg voor patiënten met diabetes ten aanzien van hun ervaringsdeskundigheid in arbeid en verkeer kunnen verbeteren. Terwijl Viola Voncken zelfmanagement van patiënten met longemfyseem probeert te verbeteren door elektronische feedback op maat. Martine Ickenroth en Janaica Gripsen onderzoeken hoe we consumenten die zelftests doen het beste kunnen informeren. Albine Moser onderzoekt hoe cliëntraden effectief kunnen bijdragen aan kwaliteit van zorg.

$$
\text { | }
$$

Tot slot de projecten die zich richten op het perspectief van zorgverlener én patiënt. Marije Koelewijn onderzoekt hoe we in het opstellen van de richtlijnen al rekening kunnen houden met het perspectief van een patiënt in de spreekkamer en Wemke Veldhuijzen exploreert hoe artspatiënt communicatie verbeterd kan worden door doelgerichter te communiceren. En Anneke de Vries kijkt hoe praktijkondersteuners meer aandacht kunnen geven aan het omgaan met diabetes in het dagelijkse leven.

We doen dus zowel observationeel / beschrijvend als experimenteel onderzoek, en veel mixed methods designs (Lewin 2009). Meestal zijn artsen de eenheid van onderzoek. We gebruiken bij het ontwikkelen van de implementatiestrategieën de theorieën die het beste bij het onderliggende probleem lijken te passen (Grol 2007). De kracht van implementatieonderzoekers is dat we multidisciplinair denken. Uitsluitend denkend vanuit de epidemiologie, zou ik - kortzichtig enkel inzetten op kennisoverdracht. Klinisch-epidemiologen zien namelijk het onbekend zijn met de wetenschappelijke informatie over zin en onzin van medische interventies als de kern van het kwaliteitsprobleem. Ze beschouwen het simpelweg als een kwestie van weglekken van informatie (Glasziou 2005). Gemiddeld zit er 17 jaar tussen het investeren in medisch onderzoek en, via het publiceren van een richtlijn, daadwerkelijke verandering in de klinische praktijk (Medical Research 2008). Dit proces is niet zomaar te verkorten door kennisoverdracht, het is veel complexer. Naast epidemiologen hebben we de inzichten nodig van psychologen, sociologen, economen, bedrijfskundigen, marketingsexperts, etcetera om te komen tot goede modellen voor verandering. Verandering van bovenaf opleggen werkt meestal niet. Verandering gaat meestal beter - hoewel het vaak moeizaam blijft - als het participatief, lerend, en cyclisch plaats vindt.

We leren veel uit onze projecten over meten van kwaliteit van zorg. Het meten op zich heeft veel goeds gebracht, zo is bijvoorbeeld de decubituszorg aanmerkelijk verbeterd (Halfens 2009). Het heeft ook veel aandacht in de media, het meten van prestaties van artsen en instellingen neemt een vlucht, een hoge vlucht. 


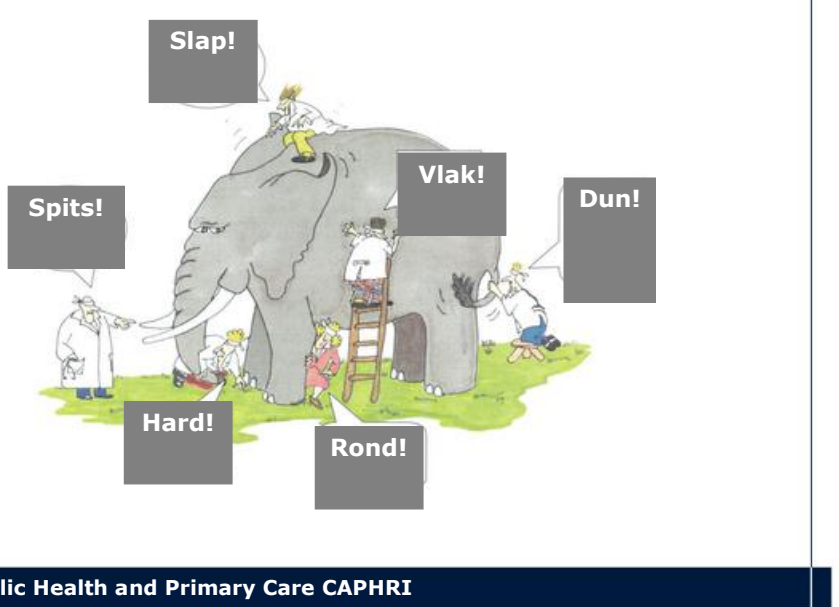

De Indische parabel van de blinde mannen en de olifant is hiervoor illustratief. Stel dat deze olifant de kwaliteit van een ziekenhuis voorstelt. Aan zes blinde mannen werd gevraagd vanuit één standpunt een beschrijving te geven van het dier, ze voelden aan de olifant en kwamen alle zes tot volledig verschillende beschrijvingen. Datzelfde zien we nu ook in de verschillende kwaliteitsmetingen in de zorg. Er is nog veel ruimte om winst te behalen met interne kwaliteitstoetsing, dus door en voor de beroepsgroep zelf, voordat de maat zo hard wordt genomen met externe kwaliteitstoetsing door beleidsmakers. Uitkomsten van indicatoren moeten we zien als het begin van een gesprek over de geleverde kwaliteit, niet als het ultieme antwoord. We moeten een balans vinden tussen controle over en vertouwen in de zorgverlener.

\section{$\underline{\text { Plannen voor onderwijs }}$}

Binnenkort komt het boek Kwaliteit en Veiligheid in Patiëntenzorg uit, waarvan ik in de redactie zit (Wollersheim 2011). Dit is een leerboek over kwaliteit van zorg voor het basiscurriculum van medische en paramedische opleidingen en gezondheidswetenschappen. De komende jaren ga ik exploreren hoe we dit onderwerp verder kunnen integreren in de opleiding tot arts en specialist, naast de bestaande colleges over kwaliteit van zorg en de Kwaliteit van Zorg opdracht in het coschap huisartsgeneeskunde. In een recent rapport zijn de thema's benoemd en hoe we als UMC's hierin van elkaar kunnen leren (Engels 2007). Ik wil aansluiten bij het onderwijs in evidence based practice, en me dan richten op variatie in zorg, meten van prestaties aan indicatoren, en patiëntgerichtheid, met gezamenlijke besluitvorming in het bijzonder.

\section{$\underline{\text { Plannen voor onderzoek }}$}


Ik ben geen theoreticus in het onderzoek, eerder een bruggenbouwer, en durf over schotten heen te kijken. Ik weet van veel een beetje, ik ben een generalist. Ik denk dat de kracht van implementatieonderzoekers is dat ze probleemgeoriënteerd denken en niet te zeer gehinderd worden door een eigen paradigma, en een eigen jargon. Ik wil een steentje bijdragen aan goede, patiëntgerichte zorg en onderzoek initiëren naar:

- Implementatie van gezamenlijke besluitvorming. Een noodzaak gezien de democratisering van de gezondheidszorg, maar ik realiseer me dat ik makkelijk praten heb als stuurvrouw aan de wal, en dat het een uitdaging is in de harde werkelijkheid van alledag. We doen dat in juni 2011 door de artsen en wetenschappers die hier wereldwijd mee bezig zijn naar Maastricht te halen, en daarbij ook patiëntvertegenwoordigers uit te nodigen. Samen met Marije Koelewijn, Anne Stiggelbout, Daniëlle Timmermans, Peep Stalmeier en vele anderen organiseer ik het twee-jaarlijkse congres over Shared Decision Making. Het thema is implementatie; moeten we vooral inzetten op het trainen van artsen of moeten we inzetten op het empoweren van patiënten? We zijn een enigszins anarchistische groep, zonder overkoepelende international society. Eigenlijk zou dit congres zichzelf moeten kunnen opheffen zodra Gezamenlijke Besluitvorming een algemeen geaccepteerd model is en volledig geïntegreerd in de Medical-Decision-Making en Communication-in-Healthcare congressen. Het moet geen eigen club met een eigen taal worden, die daardoor weer groepen buitensluit.

Daarnaast wil ik onderzoek initiëren naar:

- $\quad$ Het gebruiksvriendelijker maken van multidisciplinaire richtlijnen, en de relatie met andere producten zoals de zorgstandaarden. Hopelijk komt er een goed centraal orgaan voor richtlijnontwikkeling (CBO, Regieraad).

- Hoe het patiëntenperspectief effectief ingebracht kan worden in richtlijnontwikkeling, in de spreekkamer, en in meten van kwaliteit.

- $\quad$ Het gebruiksvriendelijk en goed toegankelijk maken van de keuzehulpen en deze koppelen aan de richtlijnen.

- $\quad$ Het in kaart brengen van de valkuilen in het meten van de prestaties van artsen en het stellen van prestatienormen.

- $\quad$ En het voorkomen van onnodige bureaucratie in zorgmonitoring, waardoor de menselijke maat en datgene wat goed gaat ondergesneeuwd raken.

- Wat verder ter tafel komt.

Ik stel me in deze leerstoel namelijk ook dienend op aan de onderwerpen, behoeften en knelpunten die er in de zorg leven, de probleemgeoriënteerde aanpak. Dat doe ik niet alleen, Ik ben erg blij dat we er in geslaagd zijn om een ZonMW Implementation Fellow voor het MUMC aan te kunnen stellen. Jose Maessen is dit voorjaar begonnen in deze rol en doet dat met verve.

In het onderzoek wil ik graag de goede samenwerking voortzetten met:

- Patiënten en patiëntvertegenwoordigers

- Collega's binnen Caphri en het MUMC

- Michel Wensing en de andere collega's van IQ healthcare

- Glyn Elwyn en de collega's van Cardiff 
- Sandra Beurskens en de collega's van Hoge School Zuyd

- $\quad$ Verzekeraars CZ en VGZ/UVIT

Ik eindig met een woord van dank. Ik dank de rector, het College van Bestuur en Martin Paul, de decaan, voor het in mij gestelde vertrouwen. Ik dank Onno van Schayck, directeur van CAPRHI, voor zijn steun voor deze leerstoel. Ik dank onze vakgroepvoorzitter Job Metsemakers. Ik vind het geweldig dat mijn leerstoel is ingebed in huisartsgeneeskunde, de medische beroepsgroep die het denken over kwaliteit en richtlijnen heeft geïnitieerd. Ik ben arts-epidemioloog maar mijn hart ligt bij de huisartsgeneeskunde. Het mooiste en het moeilijkste vak in de zorg, vind ik. Ik draag deze rede dan ook op aan de Nederlandse huisartsen, want daar mogen we heel trots op zijn.

En dan wil ik nog een woord van dank richten tot de mensen die mij gemaakt hebben tot wie ik ben. Richard Grol en André Knottnerus, mijn promotoren, ben ik veel dank verschuldigd. Richard heeft me de weg gewezen naar deze leerstoel. De leden en ex-leden van mijn programma dank ik voor de geweldige samenwerking, en alles wat ik met en van hen heb mogen leren. Het feest vanavond heb ik voor hen georganiseerd. Hier ziet $\mathrm{u}$ de onderzoekers die de lopende projecten uitvoeren. Ik sta op hun schouders. Karin Vaessen wil ik speciaal bedanken voor haar steun, en de perfecte organisatie vandaag. En dit zijn de overige leden van het programma. Ik wil speciaal Loes van Bokhoven, Ben van Steenkiste, Huibert Tange, Gaby Ronda, en Sjoerd Hobma, bedanken, voor het kritisch doorlezen van dit manuscript, maar vooral voor hun steun door de jaren heen, en de geweldige meeting die we vanmiddag gehad hebben.

Ik dank mijn Maastrichtse schoonfamilie voor hun belangstelling. Ik dank mijn broers en schoonzussen en verdere familie voor hun belangstelling en generositeit, want jullie zijn hier terwijl ik toch regelmatig verzuim op de Brabantse feestjes. Ik noem mijn broer Jeroen. Degenen die hem hebben gekend weten hoe hij vandaag gekeken zou hebben. Met die typerende glimlach, een wonderlijke mengeling van respect en spot voor dit ritueel. En hij zou het niet gezegd, maar wel gedacht hebben: “Zo zus, nu heb je eindelijk eens een fatsoenlijke jurk aan”. Ik dank mijn ouders voor hun onvoorwaardelijke liefde en steun. Als laatste dank ik mijn man Jeroen, hij heeft mij het meest gemaakt tot wie ik ben. Wie hem kent begrijpt dat ik vooral van hem heb geleerd wat kwaliteit en toewijding is. In Vera en Olmo komt het goede van onze werelden samen.

Ik heb gezegd. 


\section{Literatuurreferenties}

Acker F. New findings on unconscious versus conscious thought in decision making: additional empirical data and meta-analysis. Judgment and Decision Making 2008;3:292-303.

Baker R, Camosso-Stefinovic J, Gillies C, Shaw EJ, Cheater F, Flottorp S, Robertson N. Tailored interventions to overcome identified barriers to change: effects on professional practice and health care outcomes. Cochrane Database of Systematic Reviews 2010, Issue 3. Art. No.: CD005470. DOI: 10.1002/14651858.CD005470.pub2.

Baron J. Why Expected Utility Theory is normative, but not prescriptive. Med Dec Making 1996;16:7-9.

Bekker H, Hewison J, Thornton JG. Understanding why decision aids work: linking process and outcome. Pat Educ Couns 2003;50:323-9.

Berg M. Grip op volume. Nieuwe aandacht voor praktijkvariatie. Medisch Contact 2008;40:1647-50.

Boivin A, Légaré F, Lehoux P. Decision technologies as normative instruments: Exposing the values within. Patient Educ Couns 2008;73:426-30.

Broerse J, van der Ham L, van Veen S, Pittens C, van Tulder M. Inventarisatie patiëntenparticipatie bij richtlijnontwikkeling. Athena Instituut, Vrije Universiteit Amsterdam. 2010.

Carman KL, Maurer M, Mathews Yegian J, Dardess P, McGee J, Evers M, Marlo KO. Evidence that Consumers are Skeptical about evidence based care. Health Affairs 2010;29:1400-6.

CBO Kwaliteitsinstituut voor de gezondheidszorg, Ned Patiënten Consumenten Federatie NPCF. Blauwdruk patiëntenparticipatie in richtlijnontwikkeling. Leidraad voor richtlijnmakers. Juni 2010

Charles C, Gafni A, Whelan T: Decision-making in the physician-patient encounter: revisiting the shared treatment decision-making model. Soc Sci Med 1999, 49:651-661.

Choudhry NK, Fletcher RH, Soumerai SB. Systematic review. The relationship between clinical experience and quality of health care. Ann Intern Med 2005;142:260-73.

Conrad P. Mackie T, Mehrotra A. Estimating the costs of medicalisation. Soc Sc Med 2010;70:1943-7.

Coulter A, Jenkinson C. European patients views on the responsiveness of health systems and healthcare providers. Eur J Public Health 2005;15:355-60.

Coulter A. Do patients want a choice and does it work? BMJ 2010; 341: 14 October

Davidoff F, Haynes B, Sackett D, Smith R. EBM: a new journal to help doctors identify the information they need. BMJ 1995;310:1085-6.

Deber R, Kraetschmer N,__Urowitz S Sharpe N. Do people want to be autonomous patients? Preferred roles in treatment decision making in several patient populations. Health Expect 2007;10:248-58. 
DiMatteo MR. Variations in patients' adherence to medical recommendations: a quantitative review of 50 years of research. Med Care 2004, 42: 200-209.

Dorsey ER. De Roulet J, Thompson JP, et al. Funding of US biomedical research, 2003-2008. JAMA 2010;303:137-43.

Elwyn G, Edwards A, Kinnersley P, Grol R. Shared decision making and the concept of equipoise: the competences of involving patients in healthcare choices. Br J Gen Pract 2000;50:892-99.

Elwyn G, OÇonnor A, Stacey D, et al. on behalf of the International Patient Decision Aids Standards Collaboration. Developing a quality criteria framework for patient deicison aids: Online international Delphi consensus process. Br Med J 2006;333:417-21.

Elwyn G, Légaré F, Edwards A, van der Weijden T, May C. Arduous implementation: Does the Normalisation Process Model explain why it's so difficult to embed decision support technologies for patients in routine clinical practice. Implementation Science 2008, 3:57.

Elwyn G, O’Connor AM, Bennett C, Newcombe RG, Durand MA, Drake E, Joseph N, Khangura S, Politi M, Saarimaki A, Sivell S, Stiel M, Bernstein SJ' Col N, Coulter A, Eden K, Härter M, Holmes Rovner M, Moumjid N, Perestelo Pérez L, Stacey D, Thomson R, Whelan T, van der Weijden T, Edwards A. Assessing the quality of decision support technologies using the International Patient Decision Aid Standards instrument (IPDASi). PLOS One 2009;4(3): e4705. doi:10.1371/journal.pone.0004705

Engels Y, Wollersheim H. Verheggen F, Grol R. Eindrapport Kwaliteit van zorg onderwijs aan de faculteiten geneeskunde, biomedische wetenschappen en gezondheidswetenschappen in Nederland. Kwaliteit van Zorg WOK, UMC St Radboud, Nijmegen 2007.

Fleuren M, Wiefferink K, Paulussen T. Determinants of innovations Int J Qual Health Care 2004;16:10723.

Gafni A, Charles C, Whelan T. The physician-patient encounter: the physician as a perfect agent for the patient versus the informed treatment decision-making model. Soc Sc Med 1998;47:347-54.

Glasziou P, Haynes B. The paths from research to improved health outcomes. Evidence Based Nursing 2005;8:36-8

Grol R, Wensing M. What drives change? Med J Australia 2004;180:S57-S60.

Grol R, Wensing M, Eccles M. Improving patient care. The implementation of change in clinical practice. Elsevier 2005.

Grol R, Wensing M. Implementatie. Effectieve verbetering van de patiëntenzorg. Elsevier Gezondheidszorg, Maarssen 2006.

Grol RPTM, Bosch MC, Hulscher MEJL, Eccles MP, Wensing M. Planning and Studying Improvement in Patient Care: The Use of Theoretical Perspectives. Milbank Q 2007;85:93-138. 
Guyatt GH, Oxman AD, Vist GE, Kunz R, Falck-Ytter Y, Alonso-Coello P, Schünemann H. GRADE: an emerging consensus on rating quality of evidence and strength of recommendations. BMJ 2008, 336:924-6.

Guyatt GH, Oxman AD, Kunz R, Falck-Ytter Y, Vist GE, Liberati A, et al. Going from evidence to recommendations. BMJ 2008;336:1049-51.

Halfens R, Meijers JMM, Neyens JCL, Schols JMGA. Landelijke Prevalentiemeting Zorgproblemen LPZ. 2009 Kort en bondig. www.lpz-UM.eu.

Hochman M, McCormick D. Characteristics of published comparative effectiveness studies of medications. JAMA 2010;303:951-8.

Kinnersley P, Edwards A, Hood K, et al. Intervention s before consultations to help patients address their information needs by encouraging question asking. A systematic review. Br Med J 2008;337:335-9.

Kirwan JR, Minnock P, Adebajo A, Bresnihan B, Choy E, de Wit M, Hazes M, Richards P, Saag K, Suarez-Almazor M, Wells G, Hewlett S: Patient perspective: fatigue as a recommended patient centered outcome measure in rheumatoid arthritis. J Rheumatol 2007, 34:1174-7.

Koelewijn - van Loon MS, van Steenkiste B, Ronda G, Wensing M, Stoffers HE, Elwyn G, Grol R, van der Weijden T. Improving patient adherence to lifestyle advice (IMPALA): a cluster-randomised controlled trial on the implementation of a nurse-led intervention for cardiovascular risk management in primary care. Protocol. BMC Health Services Research 2008,8:9.

Koelewijn - van Loon MS, van der Weijden T, van Steenkiste B, Ronda G, Winkens B, Severens JL, Wensing M, Elwyn G, Grol R. Involving patients in cardiovascular risk management using nurse-led clinics: a cluster-randomised controlled trial in primary care. Can Med Ass J 2009;181:E267-74.

Lehoux P, Daudelin G, Demers-Payette O, Boivin A. Fostering deliberations about health innovation: What do we want to know from publics? Soc Sci Med. 2009;68:2002-9.

Légaré F, Stacey D, Graham ID, Elwyn G, Pluye P, Gagnon MP, Frosch D, Harrison MB, Kryworuchko J, Pouliot S, Desroches S. Advancing theories. models and measurement for an interprofessional approach to shared decision making in primary care: A study protocol. BMC Health Serv Res 2008;8:2.

Légaré F, Boivin A, van der Weijden T, Packenham C, Tapp S, Burgers J. A knowledge synthesis of patient and public involvement in clinical practice guidelines: study protocol. Implementation Science 2009, 4:30.

Légaré F, Boivin A, van der Weijden T, Pakenham C, Burgers J, Légaré J, St-Jacques S, Gagnon S. Patient and public involvement in clinical practice guidelines: a knowledge synthesis of existing programs. Prov accepted Med Dec Making 2010

Lewin S, Glenton C, Oxman AD. Use of qualitative methods alongside randomised controlled trials of complex healthcare interventions: methodological study. BMJ 2009 Sep 10;339:b3496. doi:

10.1136/bmj.b3496. 
Llewellyn-Thomas HA: Measuring patients' preferences for participating in healthcare decisions: avoiding invalid observations. Health Expect 2006, 4:305-6.

McNutt RA. Shared medical decision making: problems, process, progress. JAMA 2004;292:2516-8.

Medical research: what's it worth? Wellcome Trust, MRC, Ac Med Sciences. November 2008

www.wellcome.ac.uk/economic benefits.

Montori VM, Guyatt GH. Progress in evidence-based medicine. JAMA 2008;300:1814-6.

Moreira T. Diversity in clinical guidelines: the role of repertoires of evaluation. Soc Sci Med. 2005;60:1975-85.

Mulley AG. The need to confront variation in practice BMJ 2009;339:1007-9.

NHG Nederlands Huisartsen Genootschap: M84 Cardiovasculair Risicomanagement. In NHG-Standaarden. Volume M84. Houten, Bohn Stafleu, van Loghum; 2006:54.

NPCF Nederlandse Patiënten en Consumenten Federatie. Meldactie Zelfmanagement. "Bent u actief betrokken bij uw behandeling?" Utrecht, Nov 2010.

O’Connor AM, Bennett C, Stacey D, Barry MJ, Col NF, Eden KB, Entwistle V, Fiset V, Holmes-Rovner M, Khangura S, Llewellyn-Thomas H, Rovner DR. Do patient decision aids meet effectiveness criteria of the International Patient Decision Aid Standards Collaboration? A systematic review and meta-analysis. Med Dec Mak 2007;27:554-74.

Paling J. Strategies to help patients understand risks. Br Med J 2003;327:745-8.

RVZ Raad voor de Volksgezondheid en Zorg. De patiënt als sturende kracht. Den Haag 2010. www.rvz.net.

Rapley T. Distributed decision making: the anatomy of decisions-in-action. Soc Health\&Illness 2008;30:429-44.

Rose G. Angel Keys lecture. Circulation 1991;84:1405-9.

Sabaté E: Adherence to long-term therapies. Evidence for action. Geneva, Switzerland: WHO; 2003.

Sackett DL, Rosenberg WMC, Muir Gray JA et al: evidence based medicine: what it is and what it isn't. BMJ 1996;312:71-2.

Smith SK, Trevena L, Simpson JM, Barratt A, Nutbeam D, McCaffery KJ. A decision aid to support informed choice about bowel cancer screening among adults with low education: randomised controlled trial. BMJ 2010 Oct 26;341:c5370. doi: 10.1136/bmj.c5370. 
Stalmeier PF, van Tol-Geerdink JJ, van Lin EN, Schimmel E, Huizenga H, van Daal WA, Leer JW.

Doctors' and patients' preferences for participation and treatment in curative prostate cancer radiotherapy. $\mathrm{J}$

Clin Oncol 2007;25:3096-100.

Stolper CF, Van Royen P, van de Wiel MWJ, van Bokhoven MA, Houben PHH, van der Weijden T, Dinant GJ. Consensus on gut feelings in general practice. BMC Family Practice 2009;10:66.

Thornton H, Edwards A, Elwyn G. Evolving the multiple roles of 'patients' in health-care research: reflections after involvement in a trial of shared decision making. Health Expect 2003;6:189-97.

Thorpe KE, Zwarenstein M, Oxman AD, Treweek S, Furberg CD, Altman DG, Tunis S, Bergel E, Harvey I, Magid DJ, Chalkidou K. A pragmatic-explanatory continuum indicator summary (PRECIS): a tool to help trial designers. J Clin Epidemiol. 2009;62:464-75.

Towle A, Godolphin W, Grams G, LaMarre A. Putting informed and shared decision making into practice. Health Expectations 2006;9:321-32.

Van de Bovenkamp HM, Trappenburg MJ. Reconsidering patient participation in guideline development. Health Care Analysis 2009;17:198-216.

Van der Weijden T, Légaré F, Boivin A, Burgers JS, van Veenendaal H, Stiggelbout AM, Faber M, Elwyn G. How to integrate individual patient values and preferences in clinical practice guidelines? A research protocol. Implementation Science 2010, 5:10.

Van Dulmen S. Moving forward to improve medication adherence. Pat Educ Couns 2010;81:145-6.

Verkerk K, Van Veenendaal H, Severens JL, Hendriks EJ, Burgers JS.Considered judgement in evidencebased guideline development. Int J Qual Health Care 2006;18:365-9.

Verstappen WHJM, ter Riet G, Dubois WI $\dagger$ ), Winkens R, Grol RPTM, Weijden T van der. Variation in test ordering behaviour of general practitioners: professional or context-related factors? Fam Pract 2004;21:387-95.

Vos R, Willems D, Houtepen R. Coordinating the norms and values of medical research, medical pratice and patient worlds - the ethics of evidence based medicine in orphaned fields of medicine. J Med Ethics 2004;30:166-70.

Wennberg J, Fisher E, Skinner J. Geography and the debate over medicare reform. Health Affairs 2002; Suppl Web Exclusive, W94-114.

Wollersheim H, hoofdredacteur. Kwaliteit en veiligheid in de patiëntenzorg. Bohn, Stafleu, van Loghum. Houten 2011.

WRR Wetenschappelijke Raad voor het Regeringsbeleid. De menselijke beslisser. Over de psychologie van keuze en gedrag. WL Tiemeijer, CA Thomas, HM Prast (red). Amsterdam University Press 2009. 